\title{
PENGEMBANGAN PERANGKAT PEMBELAJARAN FISIKA MODEL LEARNING CYCLE 5E UNTUK MENINGKATKAN PEMAHAMAN KONSEP SISWA PADA MATERI FLUIDA STATIS
}

\author{
Iwan Wicaksono ${ }^{1)}$, Budi Jatmiko'), Tjipto Prastowo ${ }^{3)}$ \\ 1) Mahasiswa Program Studi Pendidikan Sains, Program Pascasarjana Universitas Negeri Surabaya \\ ${ }^{2), 3)}$ Dosen Pascasarjana Prodi Pendidikan Sains Univesrtitas Negeri Surabaya \\ E-mail: iwan.wicaksono20@gmail.com
}

\begin{abstract}
This study aims to describe the validity, practicality, and effectiveness of physics learning material based on a $5 \mathrm{E}$ learning cycle model to improve student's understanding in static fluid. Model had the best of guide student's through the stages of learning. the development of research learning using a modified 4-D model Thiagarajan (no disseminate is required) and one group pretest-posttest design. Research had done in class X SMAN 16 Surabaya Academic Year 2013/2014. Data collection techniques using observation, test, and questionnaire. Analysis using quantitative and qualitative descriptive. The results of this research are as follows: 1) the validity of RPP is found to be 3.9 which is categorized exellent, BAS is calculated 3.7 clasified exellent, LKS is calculated 3.8 clasified exellent, the legibility of BAS is found to be $74 \%$ which is categorized high, the legibility of LKS is found to be $77 \%$ which is categorized high, the difficulty of BAS is found to be $27 \%$ which is categorized easily, the difficulty of LKS is found to be $26 \%$ which is categorized easily; 2) the practicality of learning a feasibility is calculated 95\% clasified exellent and learning implementation constraints that arise when students understand the experiment steps; 3 ) the effectiveness of learning, an improved student understanding happens to the majority of respondents (33 out of 35 students) in every class test; of 14 student activities observed, it is found that $80 \%$ fits into an adequate or good category and the remaining requires futher treatment, and positive student response to learning. Based on the research results three class are consistent, it can be concluded that the developed learning material on the based of a $5 \mathrm{E}$ learning cycle model to improve student's understanding is appropriate that it can be applied in learning.
\end{abstract}

Keywords: 5 E learning cycle model, student's understanding, static fluid

Abstrak: Penelitian ini bertujuan untuk mendeskripsikan kelayakan perangkat pembelajaran fisika model learning cycle $5 E$ untuk meningkatkan pemahaman konsep siswa pada materi fluida statis. Keutamaan model ini membimbing siswa melalui tahapan-tahapan pembelajaran. Jenis penelitian adalah penelitian pengembangan untuk mengembankan perangkat pembelajaran menggungakan model 4-D oleh Thiagarajan (tahap disseminate tidak dilaksanakan) dengan rancangan ujicoba one group pretestposttest design. Penelitian dilaksanakan di kelas X SMAN 16 Surabaya pada Semester Genap Tahun Pelajaran 2013/2014. Teknik pengumpulan data menggunakan observasi, pemberian tes, dan angket. Teknik analisis data menggunakan deskriptif kuantitatif dan kualitatif. Hasil-hasil penelitian meliputi: 1) validitas perangkat pembelajaran, di mana nilai validasi RPP sebesar 3,9 berkategori sangat baik, BAS sebesar 3,7 berkategori sangat baik, LKS sebesar 3,8 berkategori sangat baik; keterbacaan BAS sebesar $75 \%$ berkategori tinggi, keterbacaan LKS sebesar 77\% berkategori tinggi; tingkat kesulitan BAS sebesar $27 \%$ berkategori mudah, tingkat kesulitan LKS sebesar 26\% berkategori mudah; 2) kepraktisan perangkat pembelajaran, di mana keterlaksanaan pembelajaran sebesar $95 \%$ berkategori sangat baik dan kendala pelaksanaan pembelajaran yang muncul saat siswa memahami langkah-langkah percobaan; 3) keefektifan perangkat pembelajaran, di mana peningkatan pemahaman konsep siswa pada mayoritas responden (33 dari 35 siswa) di setiap kelas uji; dari 14 butir aktivitas siswa yang diamati ditemukan sekitar $80 \%$ berkategori cukup baik atau baik dan sisanya masih membutuhkan penanganan lebih intensif, serta respons siswa positif terhadap pembelajaran. Berdasarkan hasil-hasil penelitian ketiga kelas yang konsisten, maka disimpulkan bahwa perangkat pembelajaran fisika model learning cycle $5 E$ untuk meningkatkan pemahaman konsep siswa pada materi fluida statis layak digunakan sehingga dapat diterapkan dalam pembelajaran.

Kata kunci: model learning cycle 5E, pemahaman konsep siswa, fluida statis

\section{PENDAHULUAN}

Tujuan pendidikan nasional dalam UndangUndang (UU) No. 20 Tahun 2003 menyatakan bahwa pendidikan nasional berfungsi mengembangkan kemampuan dan membentuk watak serta peradaban bangsa yang bermartabat dalam rangka mencerdaskan kehidupan bangsa, bertujuan untuk berkembangnya potensi peserta didik agar menjadi manusia yang beriman dan bertaqwa kepada Tuhan Yang Maha Esa, berakhlak mulia, sehat, berilmu, cakap, kreatif, mandiri, dan menjadi warga negara yang demokratis serta bertanggung jawab. Hal ini diperjelas dengan Peraturan Pemerintah (PP) No. 32 Tahun 2013 tentang standar nasional pendidikan menyatakan bahwa menjamin mutu 
pendidikan nasional dalam rangka mencerdaskan kehidupan bangsa dan membentuk watak serta peradaban bangsa yang bermartabat.

Standar Kompetensi Lulusan (SKL) Kurikulum 2013, siswa SMA memiliki sikap, pengetahuan, dan keterampilan. Berlakunya Kurikulum 2013 bertujuan untuk mempersiapkan manusia Indonesia agar memiliki kemampuan hidup sebagai pribadi dan warga negara yang beriman, produktif, kreatif, inovatif, dan afektif serta mampu berkontribusi pada kehidupan bermasyarakat, berbangsa, bernegara, dan peradaban dunia. Peraturan Menteri Pendidikan dan Kebudayaan (Permendikbud) Nomor 65 Tahun 2013 tentang standar proses pendidikan menyatakan bahwa kualifikasi kemampuan lulusan yang mencakup sikap, pengetahuan, dan keterampilan peserta didik. Proses pembelajaran pada satuan pendidikan diselenggarakan secara interaktif, inspiratif, menyenangkan, menantang, memotivasi siswa untuk berpartisipasi aktif, serta memberikan ruang yang cukup bagi prakarsa, kreativitas, dan kemandirian sesuai dengan bakat, minat, dan perkembangan fisik serta psikologis siswa.

Dalam proses pembelajaran, keberhasilan pencapaian tujuan pendidikan bergantung kepada bagaimana Kegiatan Belajar Mengajar (KBM) dirancang dan dijalankan. Proses pembelajaran merupakan salah satu tahap yang sangat menentukan terhadap keberhasilan belajar siswa. Djamarah dan Zain (2010) menyatakan indikator keberhasilan KBM meliputi: 1) daya serap terhadap bahan pengajaran yang diajarkan mencapai prestasi tinggi baik secara individual maupun kelompok; 2) perilaku yang digariskan dalam tujuan pembelajaran telah dicapai oleh siswa secara individual maupun kelompok. Pembelajaran yang diperlukan adalah pembelajaran yang tidak hanya mengulang kembali ide-ide, tetapi pembelajaran yang mampu mengeksplorasi ide-ide siswa. Hal ini dimaksudkan agar siswa bisa mendapatkan pembelajaran yang lebih bermakna (Widhi, 2012).

Pembelajaran sains termasuk fisika berhubungan erat dengan berbagai gejala alam dalam kehidupan sehari-hari. Fisika dapat dikategorikan sebagai ilmu yang bersifat induktif, yaitu ilmu yang dibangun atas dasar penyimpulan dari kejadian-kejadian di alam. Pembelajaran sains fisika tidak dapat dipisahkan dengan hukum-hukum, konsep-konsep, dan teori-teori yang sifatnya mendasar (Azis et al., 2006). Mata pelajaran fisika ditujukan untuk mengembangkan kemampuan bernalar, berpikir analitik, induktif, dan deduktif menggunakan konsep dan prinsip fisika.

Mata pelajaran fisika khususnya pada materi fluida statis pada kelas X SMA menuntut kemampuan memperoleh makna dari materi pembelajaran yang telah dipelajari. Materi fluida statis mempunyai sifat abstrak sehingga harus dikonkretkan dan terdapat konsepkonsep yang harus dipahami dengan melakukan aktivitas yang berdasarkan pengalaman siswa sehingga menemukan pengetahuan yang diharapkan. Siswa harus menemukan sendiri dan mentransformasikan informasi konsep materi fluida statis sehingga mampu memecahkan masalah secara ilmiah berdasarkan konsep yang telah diperoleh, meningkat hasil belajar siswa, dan dapat menerapkan dalam kehidupan sehari-hari.

Programme for International Student Assessment (PISA) 2012 mengukur kemampuan sains siswa di Indonesia, hasil penelitian menunjukkan skor rata-rata 382. Skor rata-rata tersebut berada pada level 2 dari 6 level yang ada yaitu siswa dapat menjelaskan konteks yang sederhana berdasarkan pengetahuan ilmiah. Hasil skor pada level tersebut memiliki kualifikasi level rendah sehingga rata-rata siswa di Indonesia mempunyai kemampuan memahami konsep yang rendah.

Observasi awal yang dilakukan di kelas X IPA 3, $X$ IPA 4, dan $X$ IPA 5 SMAN 16 Surabaya menunjukkan bahwa siswa kesulitan memahami materi yang diajarkan sehingga banyak yang tidak mencapai Kriteria Ketuntasan Minimal (KKM), siswa jarang melakukan kegiatan percobaan, guru jarang mengaitkan materi dengan kegiatan sehari-hari, dan guru tidak mengembangkan perangkat pembelajaran untuk pemahaman konsep pada siswa. Observasi awal tersebut didukung dengan preliminary studi pada siswa yang telah mendapatkan materi fluida statis dengan tujuan untuk mengukur pemahaman konsep siswa menggunakan soal pemahaman konsep. Data hasil pemahaman konsep dari 34 siswa SMAN 16 Surabaya menunjukkan tingkat pemahaman konsep yang rendah meliputi: 1) interpreting $82,94 \%$; 2) exemplifying $73,53 \%$; 3) classifying $63,26 \%$; 4) summarizing $47,06 \%$; 5) inferring $62,74 \%$; 6) comparing $60,78 \%$; dan 7) explaning $58,82 \%$. Berdasarkan data hasil tersebut, tingkat pemahaman konsep siswa masih membutuhkan peningkatan. Nilai hasil belajar fisika siswa ketiga kelas SMAN 16 Surabaya masih belum mencapai KKM yang ditetapkan sekolah sebesar 76 .

Pernyataan ini diperkuat dengan hasil diskusi lebih lanjut antara peneliti dan guru fisika di kelas tersebut yang menunjukkan bahwa rendahnya pemahaman konsep fisika dipengaruhi beberapa faktor meliputi: 1) siswa mempunyai anggapan awal bahwa fisika adalah pelajaran yang sulit; 2) penyajian pembelajaran fisika yang masih bersifat abstrak sehingga siswa kurang termotivasi; 3) Siswa kurang mampu menghubungkan pengetahuan baru dan lama yang telah diajarkan; 4) Siswa kurang berperan aktif dalam KBM; dan 5) belum terdapat perangkat pembelajaran yang dikembangkan khusus untuk meningkatkan pemahaman konsep siswa. 
Fakta tersebut didukung dengan pembelajaran yang terjadi saat ini di sekolah masih banyak yang berorientasi pada upaya pengembangan dan menguji daya ingat siswa. Pembelajaran masih cenderung berbasis hafalan teori dan tidak didasarkan pada pengalaman siswa, sehingga kemampuan siswa sekedar dipahami sebagai kemampuan menghafal (Restami et al., 2013). Proses pembelajaran seperti ini akan sulit mengembangkan hasil belajar kognitif. Siswa kurang diberikan kesempatan untuk mengembangkan tanggung jawab, rasa ingin tahu, kejujuran, sifat terbuka, obyektif, kreativitas, toleransi, kecermatan bekerja, rasa percaya diri, konsep diri positif, mengenal hubungan antara masyarakat dan sains, dan menginterpretasikan gejala alam dari sudut prinsip ilmiah.

Tingkat pemahaman siswa terhadap konsep dan prinsip fisika tidak hanya dipengaruhi oleh ketidakmampuan siswa menerima pelajaran yang disampaikan guru, tetapi juga dipengaruhi oleh kemampuan guru dalam KBM. Perangkat pembelajaran yang belum layak dan memadai berperan menentukan keberhasilan KBM. Hal ini membutuhkan perangkat pembelajaran yang sesuai untuk menyampaikan berbagai macam konsep yang diajarkan sehingga siswa dapat mengembangkan pemahaman konsep, aktif dalam KBM, dapat menggunakan konsep yang telah dipelajari ke dalam situasi yang baru, dan dapat melakukan kegiatan percobaan.

Pengembangan perangkat yang diduga dapat digunakan untuk meningkatkan pemahaman konsep siswa yaitu model learning cycle. Learning cycle adalah suatu model pembelajaran yang berpusat pada siswa (student centered). Learning cycle merupakan rangkaian tahap-tahap kegiatan yang diorganisasi sedemikian rupa sehingga siswa dapat menguasai kompetensi-kompetensi yang harus dicapai dalam pembelajaran dengan jalan berperan aktif (Lawson et al., 1989). Learning cycle adalah model pembelajaran yang berpusat pada siswa dengan membimbing melalui tahapan-tahapan pembelajaran sehingga dapat memberi perhatian pada konsep, melakukan penyelidikan, memberikan penjelasan, mengaplikasikan konsep ke dalam situasi baru, dan melakukan evaluasi (Bybee et al., 2006). Learning cycle merupakan salah satu strategi mengajar yang menerapkan model konstruktivis dan pemahaman konsep pada fase elaboration. Menurut paradigma konstruktivistik, belajar merupakan proses regulasi diri dalam menyelesikan konflik kognitif yang sering muncul melalui pengalaman konkrit, wacana kolaboratif, dan interpretasi (Taufiq, 2012).

Model learning cycle yang dikembangkan dalam Biological Science Curriculum Study (BSCS) mempunyai $5 E$ fase yaitu engagement, exploration, explanation, elaboration, dan evaluation (Bybee et al.,
2006). Setiap fase dapat diuraikan sebagai berikut: 1) engagement mendapatkan perhatian siswa, mendorong kemampuan berpikirnya, dan membantu mengakses pengetahuan awal; 2) exploration siswa melakukan aktivitas laboratorium untuk mendiskusikan konsep; 3) explanation melengkapi, menyempurnakan, dan mengembangkan konsep yang telah diperoleh siswa; 4) elaboration menerapkan konsep yang dipahami dan keterampilan yang dimiliki pada keadaan yang baru; 5) evaluation penilaian proses dan evaluasi penguasaan konsep yang diperoleh siswa.

Pemahaman merupakan tingkat kemampuan ranah kognitif memahami (C2), kemampuan yang dimiliki siswa pada tingkat ini adalah kemampuan memperoleh makna dari materi pembelajaran yang telah dipelajari dan proses kognitif yang berpijak pada kemampuan transfer (Prasetyarini et al., 2011). Belajar konsep merupakan bentuk belajar yang dilakukan dengan mengadakan abstraksi yaitu dalam semua objek yang meliputi benda, kejadian, dan orang (Bukhori, 2012). Belajar konsep menuntut kemampuan untuk menentukan ciri-ciri yang sama pada sejumlah objek yang dapat berupa ciri fisik, sebagaimana dapat diamati dalam lingkungan hidup fisik dan ciri nonfisik yang tidak dapat langsung diamati.

Krathwohl dan Anderson (2001) menyatakan bahwa siswa memahami jika dapat mengkonstruksi makna dari pesan-pesan pembelajaran, baik yang bersifat lisan, tulisan ataupun grafis, yang disampaikan melalui pengajaran, buku, atau layar komputer. Siswa memahami ketika menghubungkan pengetahuan baru dan lama atau pengetahuan baru yang masuk dipadukan dengan skema-skema dan kerangka-kerangka kognitif yang telah ada. Tujuh kategori memahami mulai dari paling rendah sampai ke paling tinggi sesuai dengan taksonomi Bloom yang telah direvisi meliputi: a) interpreting, kemampuan siswa mengubah informasi dari satu bentuk ke bentuk lain; b) exemplifying, kemampuan siswa memberikan contoh tentang konsep atau prinsip umum; c) classifying, kemampuan siswa mengetahui bahwa sesuatu (contoh) termasuk dalam kategori tertentu (konsep/prinsip); d) summarizing, kemampuan siswa mengemukakan satu kalimat yang merepresentasikan informasi yang diterima atau mengabstraksi sebuah tema; e) inferring, siswa dapat mengabstraksi sebuah konsep atau prinsip melalui proses menemukan pola dalam sejumlah contoh; f) comparing, kemampuan siswa mendeteksi persamaan dan perbedaan antara dua atau lebih objek, peristiwa, ide, masalah, atau situasi; g) explaning, kemampuan siswa membuat dan menggunakan model sebab akibat dalam sebuah sistem.

Mata pelajaran fisika khususnya pada materi fluida statis pada kelas $\mathrm{X}$ menuntut kemampuan memperoleh makna dari materi pembelajaran yang telah 
dipelajari. Materi fluida statis mempunyai sifat abstrak sehingga harus dikonkretkan dan terdapat konsepkonsep yang harus dipahami dengan melakukan aktivitas yang berdasarkan pengalaman siswa sehingga menemukan pengetahuan yang diharapkan. Harapan dalam pembelajaran model learning cycle $5 E$ untuk meningkatkan pemahaman konsep, siswa memperoleh makna dari materi pembelajaran yang telah dipelajari, mampu memecahkan masalah secara ilmiah berdasarkan pemahaman konsep yang telah diperoleh, dan dapat menerapkan dalam kehidupan sehari-hari.

\section{METODE PENELITIAN}

Penelitian ini merupakan penelitian pengembangan karena mengembangkan perangkat pembelajaran meliputi: RPP, BAS, LKS, dan tes pemahaman konsep. Perangkat pembelajaran dengan model learning cycle $5 E$ yang telah dikembangkan selanjutnya diujicobakan dalam KBM fisika di kelas pada materi fluida statis. Penelitian ini dilaksanakan di SMAN 16 Surabaya pada Semester Genap Tahun Pelajaran 2013/2014 diujicobakan pada 105 siswa di kelas X IPA 3, X IPA 4, dan X IPA 5.

Penelitian ini dilakukan melalui dua tahap, yaitu tahap I merupakan pengembangan perangkat pembelajaran dilanjutkan dengan ujicoba I, sedangkan tahap II merupakan implementasi perangkat pembelajaran dengan ujicoba II. Perangkat dikembangkan dengan menggunakan model 4-D. Thiagarajan, et al., (1974) menyatakan proses pengembangan perangkat model ini terdiri atas empat tahap yaitu tahap pendefinisian, perancangan, pengembangan, dan penyebaran. Pengembangan perangkat yang dilakukan peneliti hanya sampai pada tahap ketiga karena diterapkan terbatas sehingga model 4-D yang telah direduksi menjadi model 3-D yang dapat diperlihatkan pada Gambar 1 .

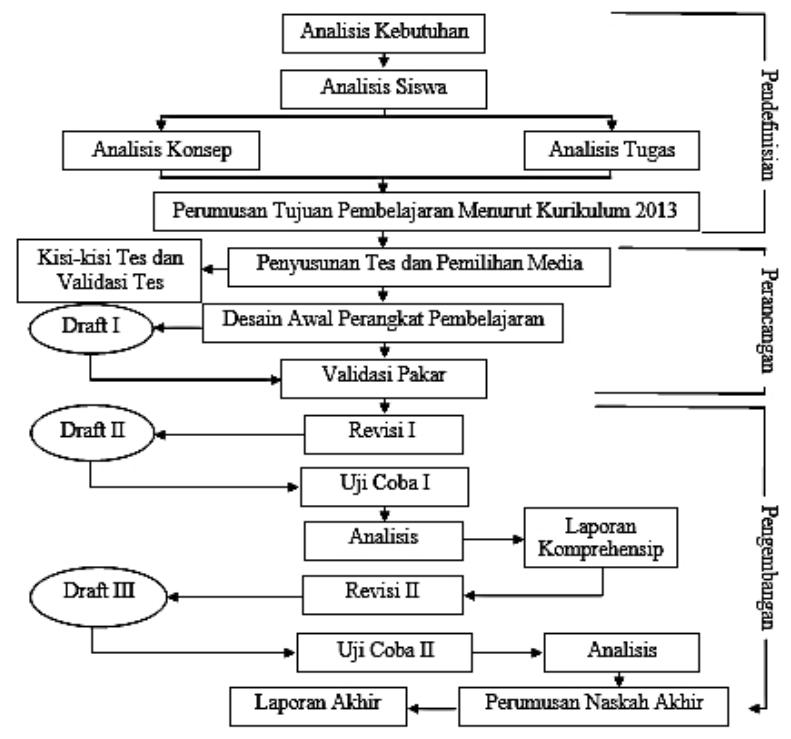

Gambar 1. Diagram Model Pengembangan Perangkat Pembelajaran (diadopsi dari Ibrahim, 2003)
Ujicoba perangkat dilakukan dengan menggunakan rancangan ujicoba one group pretestposttest design karena menggunakan satu kelompok tanpa ada kelompok pembanding. Instrumen yang dikembangkan untuk mengumpulkan data dalam penelitian meliputi: 1) lembar validitas perangkat pembelajaran terdiri atas RPP, BAS, LKS, dan tes pemahaman konsep; 2) lembar penilaian keterbacaan BAS dan LKS; 3) lembar penilaian tingkat kesulitan BAS dan LKS; 4) lembar pengamatan aktivitas siswa; 5) lembar keterlaksanaan pembelajaran; 6) lembar kendala pelaksanaan pembelajaran; 7) angket respons siswa; dan 8) tes pemahaman konsep. Pengumpulan data yang dilakukan dalam penelitian ini menggunakan teknik observasi, pemberian tes, dan penyebaran angket.

Teknik analisis data dalam penelitian ini menggunakan deskriptif kuantitatif dan kualitatif. Validitasi perangkat pembelajaran reliabel jika koefisien reliabilitas $\geq 75 \%$. Selisih antara nilai pretest dan posttest nilai tes pemahaman konsep dilakukan analisis statistik inferensial melalui analisis $N$-gain. Untuk membandingkan rata-rata dari dua variabel (pretest dan posttest) dalam satu grup data menggunakan uji $\mathrm{t}$ sampel berpasangan. Variabel pretest dan posttest untuk mengetahui korelasi sebelum dan sesudah pembelajaran. Untuk menampilkan statistik rata-rata peningkatan pemahaman konsep dan perbedaan secara signifikan ketiga kelas dilakukan uji One-Way Anova (Sugiyono, 2008).

\section{HASIL PENELITIAN DAN DISKUSI}

\section{A. Validitas Perangkat Pembelajaran}

RPP yang dikembangkan model learning cycle $5 E$ untuk pemahaman konsep siswa pada materi fluida statis. Nilai rata-rata validasi dari dua orang validator sebesar 3,9 berkategori sangat baik dengan reliabilitas instrumen sebesar $85,7 \%$ sehingga RPP dapat digunakan dan reliabel.

BAS yang telah dikembangkan oleh peneliti mencakup materi fluida statis meliputi: 1) tekanan hidrostatis; 2) hukum Pascal; dan 3) hukum Archimedes. Nilai rata-rata validasi dari dua orang validator sebesar 3,75 berkategori sangat baik dengan reliabilitas instrumen sebesar $85,7 \%$ sehingga BAS dapat digunakan dan reliabel.

LKS yang telah dikembangkan oleh peneliti mencakup materi fluida statis dan LKS terdapat elaborasi untuk menambah pemahaman konsep siswa meliputi: 1) tekanan hidrostatis; 2) hukum Pascal; dan 3) hukum Archimedes. Nilai rata-rata validasi dari dua orang validator sebesar 3,8 berkategori sangat baik dengan reliabilitas instrumen sebesar $85,7 \%$ sehingga LKS dapat digunakan dan reliabel. 
Tes pemahaman konsep untuk mengukur peningkatan pemahaman konsep siswa pretest dan posttest. Tes pemahaman konsep materi fluida statis terdiri atas 21 soal pilihan ganda. Nilai rata-rata validasi dari dua orang validator sebesar 4 berkategori tanpa revisi dengan reliabilitas instrumen sebesar 100\% sehingga tes pemahaman konsep dapat digunakan tanpa revisi dan reliabel.

Hasil ujicoba yang dilakukan pada 15 siswa menunjukkan keterbacaan BAS sebesar 75,17\% sehingga dapat dikategorikan keterbacaan tinggi dan keterbacaan LKS sebesar 77,8\% sehingga dapat dikategorikan keterbacaan tinggi. Tingkat kesulitan BAS sebesar $27,04 \%$ sehingga dapat dikategorikan tingkat kesulitan rendah atau mudah dipahami. Tingkat kesulitan LKS sebesar $26,51 \%$ sehingga dapat dikategorikan tingkat kesulitan rendah atau mudah dipahami.

\section{B. Kepraktisan Perangkat Pembelajaran}

Proses pembelajaran yang dikembangkan menggunakan RPP dengan model learning cycle $5 E$. Setiap fase proses KBM model learning cycle $5 E$ dapat diuraikan sebagai berikut: 1) engagement mendapatkan perhatian siswa, mendorong kemampuan berpikirnya, dan membantu mengakses pengetahuan awal; 2) exploration siswa melakukan aktivitas laboratorium untuk mendiskusikan konsep; 3) explanation melengkapi, menyempurnakan, dan mengembangkan konsep yang telah diperoleh siswa; 4) elaboration menerapkan konsep yang dipahami dan keterampilan yang dimiliki pada keadaan yang baru; 5) evaluation penilaian proses dan evaluasi penguasaan konsep yang diperoleh siswa. dapat ditunjukkan dengan diagram pada Gambar 2.

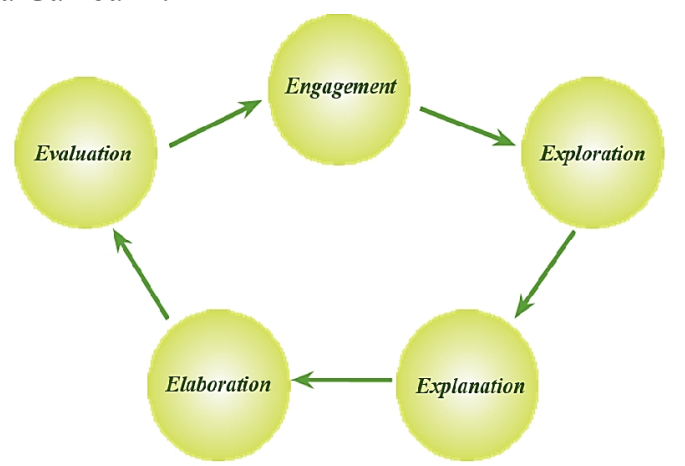

(Bybee, 1997)

Gambar 2. Fase model learning cycle $5 E$

Rata-rata keterlaksanaan RPP siswa kelas X IPA 3 sebesar 3,72 dengan kategori terlaksana sangat baik, kelas X IPA 4 sebesar 3,85 dengan kategori terlaksana sangat baik, dan kelas X IPA 5 sebesar 3,9 dengan kategori terlaksana sangat baik. Persentase keterlaksanaan RPP siswa ketiga kelas konsisten sebesar 95,6\% dengan kategori terlaksana sangat baik.
Instrumen keterlaksanaan yang diamati meliputi: 1) pengelolaan KBM memperoleh nilai rata-rata 3,79 sehingga sesuai dengan pendahuluan, isi, dan penutup; 2) pengelolaan waktu memperoleh nilai rata-rata 4 sehingga sesuai dengan alokasi waktu; dan 3) suasana memperoleh nilai rata-rata 4 sehingga sesuai dengan banyaknya antusias dari siswa dan guru.

Kendala dan alternatif solusi pelaksanaan pembelajaran konsisten meliputi: 1) siswa mengalami kesulitan untuk membedakan jenis fluida pada percobaan tekanan hidrostatis karena warna jenis fluida hampir sama sehingga alternatif solusi yaitu membedakan jenis fluida yang digunakan dengan memberikan warna; 2) kurangnya pemahaman siswa terhadap langkah-langkah percobaan karena siswa belum terbiasa dengan LKS yang diberikan sehingga alternatif solusi yaitu menjelaskan secara jelas langkahlangkah percobaan, alat dan bahan, tabel hasil pengamatan; 3) terdapat siswa yang masih kesulitan membuat kesimpulan karena siswa belum terbiasa dengan LKS yang diberikan dan merupakan pembelajaran yang baru sehingga alternatif solusi yaitu me-review percobaan yang telah dilakukan dengan dikaitkan materi fluida statis; 4) siswa kurang terbiasa membuat hipotesis dan variabel-variabel dalam percobaan karena siswa belum terbiasa dengan LKS yang diberikan dan merupakan pembelajaran yang baru sehingga alternatif solusi yaitu menjelaskan definisi dan memberikan contoh membuat hipotesis dan variabelvariabel dalam percobaan; dan 5) penggunaan necara pegas pada percobaan hukum Archimedes yang masih belum dipahami siswa karena keterampilan yang kurang dalam menggunakan alat ukur neraca pegas sehingga alternatif solusi yaitu mendemontrasikan cara mengunakan neraca pegas dan satuan yang digunakan untuk menimbang.

\section{Keefektifan Perangkat Pembelajaran}

Tujuh kategori pemahaman konsep dianalisis dengan mengelompokkan soal pilihan ganda tingkat pemahaman konsep meliputi: 1) interpreting; 2) exemplifying; 3) classifying; 4) summarizing; 5) inferring; 6) comparing; dan 7) explaning. Persentase tingkat pemahaman konsep melalui hasil pretest dan posttest. Persentase tingkat pemahaman konsep pretest siswa ketiga kelas menunjukkan semakin tinggi tingkat pemahaman konsep, maka semakin rendah persentasenya. Hasil pretest yang rendah tersebut diakibatkan kemampuan awal siswa untuk memahami materi fluida statis yang kurang dan semakin tinggi tingkat pemahaman konsep mempunyai tingkat kesulitan lebih kompleks. Persentase tingkat pemahaman konsep posttest siswa ketiga kelas menunjukkan peningkatan yang signifikan dapat ditunjukkan dengan diagram pada Gambar 3. 


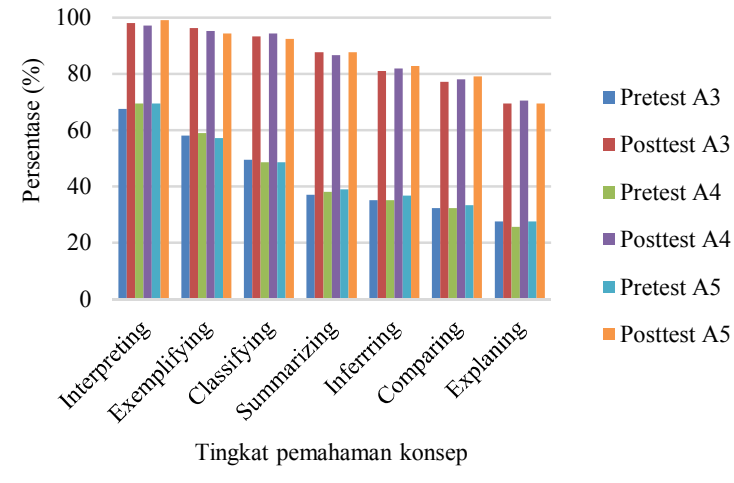

Gambar 3. Persentase tingkat pemahaman konsep

Peningkatan pemahaman konsep ketiga kelas dipengaruhi oleh beberapa faktor meliputi: 1) proses pembelajaran model learning cycle $5 E$ yang terlaksana dengan baik dari setiap tahap terutama elaboration yang mendorong siswa memperdalam konsep yang telah dipahami; 2) siswa terdorong untuk melakukan 14 butir aktivitas yang mendukung dalam memahami konsep; dan 3) siswa ketiga kelas memberikan respons yang positif terhadap ketertarikan, kemutakhiran, tingkat kesulitan, model pembelajaran, tingkat kesulitan pembelajaran, dan soal pemahaman konsep. Peningkatan pemahaman konsep siswa berhubungan dengan pembelajaran model learning cycle $5 E$ yang didukung teori konstruktivis, teori pembelajaran penemuan Bruner, teori perkembangan kognitif Piaget, teori sosial pembelajaran Vygotsky (Bybee et al., 2006). Teori-teori tersebut dapat disimpulkan, siswa harus menemukan sendiri dan mentransformasikan informasi kompleks melalui keterlibatan aktif dengan konsep dan prinsip melalui tahapan yang dicirikan oleh kemunculan dan cara mengolah informasi yang baru sehingga terdapat perkembangan intelektual berdasarkan konteks yang dialami. Siswa memahami konsep ketika menghubungkan pengetahuan baru dan lama atau informasi baru masuk dipadukan dengan skema-skema dan kerangka-kerangka kognitif yang telah ada (Krathwohl dan Anderson, 2001).

Hasil pretest dan posttest dilakukan uji statisitk normalitas untuk mengetahui distribusi data sehingga dapat dilakukan uji t sampel berpasangan. Hasil uji statistik menunjukkan ketiga kelas mempunyai data posttest yang terdistribusi normal, terdapat perbedaan nilai pretest dan posttest. Peningkatan pemahaman konsep siswa ketiga kelas menggunakan perhitungan $N$ gain pada pretest dan posttest dengan kategori tinggi $g$ $>0,70$ dan sedang $0,30<g<0,70$. Perhitungan $N$-gain siswa dari ketiga kelas konsisten menunjukkan mayoritas (33 dari 35 siswa) berada pada kategori tinggi. Hasil rata-rata $\mathrm{N}$-gain ketiga kelas dilakukan uji statistik normalitas untuk mengetahui distribusi data sehingga dapat dilakukan uji One-Way Anova. Hasil uji statistik menunjukkan ketiga kelas mempunyai data rata-rata $\mathrm{N}$-gain yang terdistribusi normal dan rata-rata ketiga kelas adalah identik sehingga sesuai memberikan hasil yang konsisten terhadap perangkat pembelajaran model learning cycle $5 E$.

Proses KBM siswa dituntut untuk aktif, pengamatan aktivitas siswa dilakukan oleh dua pengamat. Aktivitas siswa yang diamati meliputi membaca (mencari informasi), mendiskusikan tugas, mendengarkan penjelasan guru, merumuskan hipotesis, mengidentifikasi variabel manipulasi, mengidentifikasi variabel kontrol, mengidentifikasi variabel respon, melakukan percobaan, mengumpulkan data, mempresentasikan hasil percobaan, bertanya, berpendapat, menganalisis data, dan membuat kesimpulan. Persentase aktivitas siswa ketiga kelas konsisten dari pertemuan pertama, kedua, dan ketiga mengalami peningkatan. Hal tersebut terjadi karena siswa mulai terbiasa dengan pembelajaran menggunakan perangkat yang telah dikembangkan.

Angket respons siswa terhadap pembelajaran model learning cycle $5 E$ untuk melihat tanggapan siswa yang meliputi: ketertarikan, kemutakhiran, tingkat kesulitan, model pembelajaran, tingkat kesulitan pembelajaran, dan soal pemahaman konsep. Secara keseluruhan siswa ketiga kelas konsisten memberikan respons positif terhadap pembelajaran model learning cycle $5 E$ untuk meningkatkan pemahaman konsep siswa.

\section{KESIMPULAN}

\section{A. Simpulan}

Berdasarkan hasil temuan penelitian, nampak bahwa perangkat pembelajaran fisika model learning cycle $5 E$ untuk meningkatkan pemahaman konsep siswa pada materi fluida statis layak digunakan. Kelayakan perangkat pembelajaran memenuhi kriteria kevalidan yaitu validitas konseptual, keterbacaan maupun tingkat kesulitan BAS dan LKS, kepraktisan yaitu keterlaksanaan dan kendala pelaksanaan pembelajaran, dan keefektifan yaitu peningkatan pemahaman konsep, aktivitas siswa, dan respons siswa.

\section{B. Saran}

Berdasarkan penelitian ujicoba yang telah dilakukan dan hasil yang didapat, disarankan beberapa hal sebagai berikut.

1. Persiapan alat dan bahan maupun pengelolaan alokasi waktu untuk melakukan tahap exploration karena siswa harus melakukan percobaan.

2. Tahap elaboration memperdalam pemahaman konsep siswa sehingga harus diperhatikan 
3. Perangkat pembelajaran model learning cycle $5 E$ dapat meningkatkan pemahaman konsep siswa diterapkan pada materi lain.

\section{REFERENSI}

Azis, A., Yulianti, D., Handayani, L. (2006). Penerapan Model Pembelajaran Kooperatif dengan Memanfaatkan Alat Peraga Sains Fisika (Materi Tata Surya) untuk Meningkatkan Hasil Belajar dan Kerjasama Siswa. Jurnal Pend. Fisika Indonesia, Vol. 4 No 2, 94-99.

Bukhori, F. (2012). Pembelajaran Berbasis Inkuiri untuk Optimalisasi Pemahaman Konsep Fisika pada Siswa Di SMA Negeri 4 Magelang, Jawa Tengah. Jurnal Berkala Fisika Indonesia Vol. 4 No $1 \& 2$ 11-21.

Bybee,.R. W., Taylor, A. J., Gardner, A., Scotter, P. V., Poweel, J. C.,Westbrook, A., dan Landes, N. (2006). The BSCS 5E Instructional Model: Origins and Effectiveness. Colorado: Biological Science Curriculum Study.

Djamarah, B. S., Zain, A. (2010). Strategi Belajar Mengajar. Jakarta: PT Rineka Cipta.

Ibrahim, M. 2003. Pengembangan Perangkat Pembelajaran, Direktorat Pendidikan Lanjut Pertama, Dirjen Pendidikan Dasar dan Menengah, Departemen Pendidikan Nasional. Surabaya: Unesa University Press.

Krathwohl, D. R. dan Anderson, L. W. (2001). A Taxonomy for Learning, Teaching, and Assessing: A Revision of Bloom's Taxonomy of Educational Obejctives. New York: Longman.

Lawson, A. E., Abraham, M. R., dan Renner, J. W. (1989). A Theory of Instruction: Using The Learning Cycle to Teach Science Concept and
Thinking Skills. Cincinnati: University of Cincinati.

PISA. (2012). What Students Know and Can DoStudent Performance in Mathematics, Reading and Science (Volume I). London, OECD Publishing.

Prasetyarini, A., Fatmaryanti, S., Akhdinirwanto, R. (2012). Pemanfaatan Alat Peraga IPA untuk Peningkatan Pemahaman Konsep Fisika pada Siswa SMP Negeri I Buluspesantren Kebumen Tahun Pelajaran 2012/2013. Jurnal Radiasi 2 (1) $1-5$.

Restami, M., Suma, K., Pujani, M. (2013). Pengaruh Model Pembelajaran POE (Predict-ObserveExplaint) terhadap Pemahaman Konsep Fisika dan Sikap Ilmiah Ditinjau dari Gaya Belajar Siswa. E-Journal Program Pascasarjana Universitas Pendidikan Ganesha Program Studi IPA 3 (2) 1-11.

Sugiyono, (2008). Statistika untuk Penelitian. Bandung: Alfabeta

Taufiq, M. (2012). Remediasi Miskonsepsi Mahasiswa Calon Guru Fisika pada Konsep Gaya melalui Penerapan Model Siklus Belajar (Learning Cycle) 5E. Jurnal Pendidikan IPA Indonesia 1 (2) $198-203$.

Thiagarajan, S. (1974). Instructional Development for Training Teacher of Exceptional Children A Sourcebook. Indiana: Indiana University.

Widhy, P. (2012). Learning Cycle Sebagai Upaya Menciptakan Pembelajaran Sains yang Bermakna. Prosiding Seminar Nasional Penelitian, Pendidikan dan Penerapan MIPA, Fakultas MIPA, Universitas Negeri Yogyakarta. 